\title{
Erratum to: Seismic hazard assessment for Cyprus
}

\author{
Zehra Cagnan · Gulum Birgoren Tanircan
}

Published online: 13 November 2009

(C) Springer Science + Business Media B.V. 2009

\section{Erratum to: J Seismol DOI 10.1007/s10950-009-9163-1}

Unfortunately, the bibliographic reference Algermissen and Rogers (2004) was incorrect and should appear as "Rogers, AM, Algermissen, ST (2005) A Cyprus earthquake hazard assessment: maps of probabilistic peak ground acceleration and pseudo-absolute acceleration spectral response. In: DeCoster, M, Zomeni, Z, Panayides, I, Petrides, G, Berksoy, O (eds) Seismic hazard and risk assessment of the greater Nicosia Area, Revised 2005, UNOPS, Nicosia, Cyprus, 69 p"

The online version of the original article can be found at http://dx.doi.org/10.1007/s10950-009-9163-1.

Z. Cagnan $(\bowtie)$

Middle East Technical University-Northern

Cyprus Campus, Guzelyurt, KKTC, Mersin 10, Turkey

e-mail: cagnan@metu.edu.tr

G. B. Tanircan

Kandilli Observatory and Earthquake Research Institute, Bogazici University, Istanbul, Turkey

e-mail: birgore@boun.edu.tr 